\author{
AgNiESZKA BęDKOWSKA-KOPCZYK \\ Inštitut za slavistiko, Univerza Karla in Franca v Gradcu
}

\title{
Red. prof. dr. Emil Tokarz - sedemdesetletnik
}

Redni profesor dr. Emil Tokarz je zelo pomemben raziskovalec slovenskega jezika, ugledni jezikoslovec in slovenist, največji ambasador slovenskega jezika na Poljskem. Trahit sua quemque voluptas. Če za koga, potem te Vergilijeve besede veljajo za prof. dr. Emila Tokarza, ki je svoje življenje in delo posvetil jezikoslovni znanosti, predvsem slovenskemu jeziku in njegovemu uveljavljanju na Poljskem in v Evropi. Slovenistika na Poljskem je zadnjih nekaj desetletij najtesneje povezana z njegovim imenom, univerzitetni študij slovenskega jezika in književnosti na Poljskem pa si je brez Emila Tokarza danes težko predstavljati - najmočnejša slovenistična centra na Poljskem sta na Šlezijski univerzi in Univerzi Bielsko-Biała, na njih študira slovenistiko največ študentov izven Slovenije in obe slovenistični univerzitetni središči na Poljskem sta slovenistiko razvili pod njegovim vodstvom, z njegovim osebnim prizadevanjem in ljubeznijo do slovenskega jezika. Prof. dr. Emil Tokarz je eden izmed največjih ambasadorjev slovenskega jezika v svetu, prvo ime slovenistike in slovenističnega univerzitetnega študija na Poljskem.

Prof. dr. Emil Tokarz se je rodil 6. 10. 1944 v Chodorovu blizu Lvova. Drugostopenjski študij slovanske filologije je končal leta 1968 na Jagelonski univerzi, nato pa se je v študijskem letu 1969/70 izpopolnjeval iz slovenskega jezika na Filozofski fakulteti v Ljubljani pri mentorju prof. dr. Jožetu Toporišiču. Jezikoslovje, informatiko in romanistiko je podiplomsko študiral na Département de Linguistique et Informatique, UER des Lettres, Université B. Pascal, Clermont-Ferrand, Francija (od 1. 10. 1984-30. 06. 1988). Doktoriral je leta 1973 na Univerzi Mikołaja Kopernika v Torunju z disertacijo Konstrukcje parataktyczne w języku słoweński (promotor: prof. dr. hab. Leszek Moszyński, recenzenti: prof. dr. hab. Wacław Cimochowski, prof. dr. hab. Leszek Bednarczuk); habilitacijo je dosegel leta 1987 v Opolu - Nomina actionis we współczesnym języku słoweńskim (recenzenci: prof. dr. Martina Orožen, prof. zw. dr. hab. Antoni Furdal, prof. zw. dr. hab. Marian Jurkowski); danes je habilitirani redni profesor za jezikoslovje na Šlezijski univerzi in na Univerzi Bielsko-Biała. 
Raziskovalno delo prof. dr. Emila Tokarza je ves čas tesno povezano z južnoslovanskim jezikoslovjem in osredotočeno na vprašanja slovenske sintakse in didaktike poučevanja slovenščine kot tujega jezika. Poljski javnosti, predvsem univerzitetnim in akademskim krogom, z veliko ljubeznijo približuje in razlaga najnovejše znanstvene in kulturne dosežke Slovencev, slovenskega jezika, literature in kulture. Znanstveno delo prof. dr. Emila Tokarza, ki je neposredno povezano s slovenskim jezikoslovjem, obsega 92 bibliografskih enot, med drugim 6 znanstvenih monografij, 45 izvirnih znanstvenih člankov, ki so objavljeni v najuglednejših poljskih, slovenskih in drugih evropskih znanstvenih revijah, 2 slovarja, 21 strokovnih člankov, veliko znanstvenih recenziji, spremnih besed in predgovorov, 2 polemiki, sodeloval je na 90 znanstvenih konferencah, več jih je tudi sam organiziral ..., uredil pa je tudi 16 zbornikov in znanstvenih monografij o slovensko-poljskih jezikovnih stikih.

S slovenistiko se je začel ukvarjati leta 1968, ko se je udeležil IV. Seminarja slovenskega jezika, literature in kulture. Profesorja Kazimir Polański in Matjaž Kmecl sta ga usmerila in navdušila za Slovenijo, slovenski jezik in kulturo, nato pa se je z doktorsko disertacijo iz skladenjske podobe slovenskega jezika (Parataktične konstrukcije v sodobni slovenščini - mentor: L. Moszyński) znanstveno in raziskovalno dokončno posvetil slovenistiki in slovenskemu jeziku. Po enoletnem študijskim bivanju na Oddelku za slovenski jezik in književnost na Univerze v Ljubljani (1970) je na Poljskem organiziral lektorat slovenskega jezika najprej na Univerzi N. Kopernika v Torunju, nato pa leta 1974 še na Šlezijski univerzi v Katovicah. Po osamosvojitvi Slovenije je leta 1990 lektorat v Katovicah preoblikoval v samostojen oddelek za študij slovenskega jezika, literature in kulture, ki je kmalu prerasel v osrednje poljsko slovenistično univerzitetno središče, na katerem je profesor. Tokarz izšolal in vzgojil številne poljske diplomante sloveniste, tudi magistrande in doktorje znanosti. Na Šlezijski univerzi je v 90-ih letih prejšnjega stoletja ustanovil novo študijsko smer: slovensko filologijo. Gre za specializacijo, ki študentom ponuja didaktično, jezikovno, literarno in kulturološko izobrazbo v triletnem prvostopenjskem, dvoletnem magistrskem in štiriletnem doktorskem študiju. Prof. dr. Emil Tokarz se je zavedal, da je samostojen specialistični študij slovenistike na Šlezijski univerzi nujnost, ki so jo zahtevale novonastale razmere v Srednji Evropi in na Balkanu. V poljskih univerzitetnih krogih je odločno opozoril na vprašanje jezikovne unifikacije (študij slovenistike se je /zavestno/ zapostavljal zaradi srbohrvatistike), hkrati pa je tudi zahteval, da se morajo t. i. nacionalni jeziki v nekdanji Jugoslaviji (bosanski, hrvaški, srbski, danes še črnogorski) normirati kot novi samostojni knjižni jeziki v novonastalih državah bivše SFRJ. Prizadeval si je, da bi Poljaki spoznali prave novonastale jezikovne, kulturne, politične in družbene odnose med vsemi južnimi Slovani. Ime prof. dr. Emila Tokarza je tako povezano s prvo ustanovitvijo slovenističnih študij v zgodovini poljske slavistike - Šlezijska univerza je postala najboljši možni vzgled za ostala akademska središča na Poljskem, ki so se nekaj let kasneje sledila prof. Tokarzu pri ustanavljanju samostojnih slovenističnih študij (univerze v Varšavi, Łodžu in Bielsko-Biali, nazadnej tudi v Gdansku). Pionirsko delo prof. Tokarza je na 
Poljskem obrodilo sadove, ki jih je bilo na začetku težko pričakovati: leta 2010 je študij slovenskega jezika mogoče študirati na šestih državnih univerzah kot redni bolonjski do- in podiplomski študij (Šlezijska univerza, Univerza v Bielskem-Białi, Varšavska univerza in Univerza v Lodžu) ali kot lektorat (Jagelonska univerza v Krakovu in Univerza v Gdansku); trenutno je na Poljskem redno vpisanih 500 dodiplomskih študentov slovenskega jezika in 10 doktorandov.

Prof. dr. Emil Tokarz se je po uspešno organiziranem študiju slovenistike na Šlezijski univerzi spopadel z novim velikim izzivom. Na predvsem tehnično usmerjeni Univerzi Bielsko-Biała se je odločil za širitev humanističnih študij in vzpostavitev slovenistike kot samostojne študijske smeri. Zahtevne naloge se je lotil leta 2002 in danes je slovenistika na univerzi ena izmed najmočnejših jezikovnih smeri s skoraj 100 dodiplomskimi bolonjskimi študenti, petimi profesorji in več mladimi asistenti, prof. Tokarz pa je dekan fakultete, na kateri deluje največji slovenistični oddelek izven Slovenije.

Raziskovalno delo prof. dr. Emila Tokarza izhaja iz odličnega poznavanja jezikoslovnih in metodoloških vprašanj slovenskega knjižnega jezika, njegovega zgodovinskega razvoja in narečne razčlenjenosti. V globalnem evropskem in svetovnem prostoru si ob dobrem sodelovanju prizadeva predvsem za promocijo in uveljavljanje slovenskega jezika $\mathrm{v}$ univerzitetnih, znanstvenih in raziskovalnih krogih. Njegov pogled na slovenski jezik »od zunaj« je za slovenske jezikoslovce dragoceno merilo, s katerim nas opozarja na vprašanja, ki bi jih ali spregledali ali videli v drugačni luči. Opozarja nas, da je slovenski jezik sicer eden izmed uradnih jezikov Evropske zveze, vendar pa ga v praksi vse prepogosto in nekritično predvsem $\mathrm{v}$ znanosti nadomeščamo z globalno angleščino. $\mathrm{Na}$ osnovi poljske izkušnje nas prepričuje, da angleščina ni in ne sme postati univerzalni učni jezik ter edini jezik znanosti in univerzitetnih krogov. Profesor Emil Tokarz nas »od zunaj « nenehno opozarja, da izrinjanje nacionalnih jezikov iz univerzitetnih predavalnic in nadomeščanje nacionalnega znanstvenega jezika $\mathrm{z}$ nadomestnim angleškim $\mathrm{v}$ objavah neangleških raziskovalcev in znanstvenikov pomeni začetek konca takega nacionalnega jezika.

Profesor Tokarz pripada tistemu rodu jezikoslovcev, ki se zavedajo, da sta znanost in kultura najvišji vrednoti, ki ju zmorejo ceniti le narodi, ki dajo kaj nase. Jezik pojmuje kot pojav, ki si sam ohranja in razvija sposobnost za ubesedovanje potreb dane jezikovne skupnosti. Kot poljski jezikoslovec, ki mu je še kako mar za slovenski jezik, se zavzema za jezikovno odprtost, jezikovno kulturo in jezikovno predanost, opozarja pa pred negativno jezikovno asimilacijo, ki se v imenu globalizacije, modnosti in eksibicionizma poskuša uveljaviti v znanosti in raziskovanju, politiki ter posameznih strokah, tudi v šolstvu. Poseben poudarek si zasluži njegovo upoštevanje strokovne literature z drugih področij humanistike in sposobnost povezovanja ter ustvarjalnega upoštevanja njihovih ugotovitev pri raziskavah slovenskega gradiva. Pri jezikoslovnem delu sta zanj značilna miselni red in natančnost, ki ju nadgrajuje z obsežnim in poglobljenim znanjem iz slovenskega, slovanskega in splošnega jezikoslovja ter sposobnost, da povezuje in nadgrajuje spoznanja različnih jezikoslovnih smeri in šol. 
Profesor Emil Tokarz, ambasador slovenskega jezika in slovenistične znanosti na Poljskem, povezuje Slovenijo in Poljsko, za slovenski jezik navdušuje vedno nove generacije poljskih študentov, kot posrednik med obema jezikoma in kulturama pa živi med Mariborom in Bielskim-Biało, med Ljubljano in Katovicami, med Koprom in Vislo. Na Poljskem je spodbujal in navduševal slovenske lektorje za delo s poljskimi slovenisti (Toneta Pretnarja, Vlada Nartnika, Mladena Pavičiča, Jano Unuk, Silvijo Borovnik, Matejo Tirgušek, Andreja Šurlo ...), hkrati pa je nenhno prisoten na vseh pomembnih slovenističnih dogodkih v Sloveniji (npr. SSJLK, Obdobja, Poletna šola slovenskega jezika v Kopru in Bovcu, Zborovanje slavistov, slovensko-poljski simpoziji na univerzah v Mariboru, Kopru in Ljubljani, Škrabčeva misel, Plerešnikovi dnevi, Mednarodni dialektološki simpozij v Mariboru ...) in po Evropi. Profesor Emil Tokarz je bil mentor diplomskim študentom na univerzah v Mariboru in Kopru, strokovni poročevalec mlajšim slovenskim slovenistom v habilitacijskih postopkih, gostujoči profesor v Ljubljani, Mariboru in Kopru in cenjen predavatelj na mariborski slovenistiki, kamor se vedno rad vrača kot profesor, mentor ali poročevalec $\mathrm{v}$ raznih komisijah.

Več kot tridesetletno delo v slovenistični stroki upravičeno postavlja profesorja Emila Tokarza na vrh najzaslužnejših tujih slovenistov - delo, ki ga je opravil za promocijo slovenskega jezika in študij slovenistike na tujih univerzah, je neprecenljive vrednosti za promocijo Slovenije in v prihodnosti še čaka na primerno oddolžitev s strani slovenske države.

\section{Prof. zw. dr hab. Emil Tokarz - jubileusz siedemdziesięciu lat}

Emil Tokarz urodził się 6 października 1944 w Chodorowie koło Lwowa. Swoją naukową podróż rozpoczął w roku 1963 na Uniwersytecie Jagiellońskim w Krakowie, gdzie studiował filologię słowiańską. W roku 1968 obronił pracę magisterską, której promotorem był prof. dr. hab. Stanisław Urbańczyk, a recenzentem prof. dr. hab. Franciszek Sławski. Po studiach rozpoczął pracę na Uniwersytecie Mikołaja Kopernika w Toruniu, gdzie pracował najpierw jako asystent, a następnie - do roku 1973 - jako docent. W tym czasie jego zainteresowania badawcze wzbudził język słoweński. Na Wydziale Filozoficznym Uniwersytetu w Lublanie, pod promotorską opieką prof. dr. Jože Toporišiča, realizował językoznawcze słowenistyczne studia doktoranckie (1969-1970). W roku 1973 obronił pracę doktorską zatytułowaną Konstrukcje parataktyczne w języku słoweńskim, której promotorem był prof. dr hab. Leszek Moszyński. 
Następnie zatrudnił się na Uniwersytecie Śląskim, gdzie zorganizował studia slawistyczne, Katedrę Slawistyki, a następnie Instytut Slawistyki (którym przez wiele lat kierował i na którym w roku 1992 powołał pierwszą w Polsce filologię słoweńską). W latach 1984-1988 kształcił się na Uniwersytecie Blaise Pascal w Clermont-Ferrand (Université Blaise-Pascal) we Francji. W ramach studiów III stopnia studiował językoznawstwo ogólne i informatykę oraz językoznawstwo romańskie. W roku 1987, w Wyższej Szkole Pedagogicznej w Opolu, obronił rozprawę habilitacyjną pod tytułem Nomina actionis we wspótczesnym języku stoweńskim. Wśród recenzentów jego dorobku była m.in. prof. dr Martina Orožen. W roku 1998 otrzymał z rąk Prezydenta RP nominację na profesora zwyczajnego. Z Uniwersytetem Śląskim, gdzie wykładał nie tylko w Instytucie Filologii Słowiańskiej, ale także w Instytucie Pedagogiki oraz na Podyplomowych studiach logopedii i glottodydaktyki, związany był do roku 2002. Wtedy to przeniósł się do Akademii Techniczno-Humanistycznej w Bielsku-Białej, gdzie rozpoczął kolejne pionierskie dzieło - organizację slawistyki i studiów słowenistycznych. W Bielsku-Białej dał się poznać również jako współtwórca Wydziału Humanistyczno-Społecznego, Prorektor ds. Nauki i Współpracy Zewnętrznej, Dziekan Wydziału Humanistyczno-Społecznego, Kierownik Katedry Studiów Środkowoeuropejskich. Do dnia dzisiejszego sprawuje funkcje Kierownika Podyplomowych studiów neurologopedii, Podyplomowych studiów logopedii i glottodydaktyki i Podyplomowych studiów logopedii z komunikacją alternatywną. Od roku 2010 pracował w Katedrze Anglistyki Akademii Techniczno-Humanistycznej, którą także kierował. Obecnie zatrudniony jest w Katedrze Studiów Środkowoeuropejskich, swej macierzystej katedrze na ATH w Bielsku-Białej. W latach 2002-2007 wykładał także w Instytucie Słowiańskich Języków i Literatur Wydziału Filozoficznego Uniwersytetu w Mariborze. Wielu z jego słoweńskich studentów podążało za nim do Polski, gdzie w ramach programu Erasmus (dziś Erasmus + ) kontynuowało swą slawistyczną edukację.

Jako językoznawca Emil Tokarz poświęcił się południowosłowiańskiej i polskiej leksykologii, semantyce, morfologii i składni, a także dydaktyce języka słoweńskiego. Szczególną rolę w jego pracach badawczych odgrywają tematy z zakresu socjolingwistyki, a zwłaszcza tematy dotyczące sytuacji językowej słowiańskich diaspor zlokalizowanych na terenach słowiańskich, germańskich i romańskich (np. Łemków, Chorwatów burgenlandzkich i molizańskich). Swoje doświadczenie i wiedzę $\mathrm{w}$ tej dziedzinie wykorzystuje jako specjalista Ministerstwa Edukacji Narodowej ds. podręczników językowych, przeznaczonych dla mniejszości narodowych. Prowadzi badania w dziedzinie słowiańskiej i słoweńskiej składni, którą - zwłaszcza ostatnio - zestawia ze składnią języka angielskiego. Wiele jego prac poświęconych jest słoweńsko-polskim kontaktom językoznawczym, naukowym i kulturowym. Interesują go również zagadnienia dotyczące glottodydaktyki i logopedii oraz neurologopedii.

Emil Tokarz zorganizował lub współorganizował ponad dwadzieścia konferencji naukowych w Polsce i Słowenii, a swoje prace badawcze zaprezentował na ponad dziewięćdziesięciu konferencjach, kongresach i seminariach na całym świecie (w Europie i Kanadzie). W formie książkowej ukazało się wiele jego 
rozpraw i słowników. Spośród nich trzeba wspomnieć zwłaszcza o czterech: Składni zdań złożonych wspótrzędnie w języku słoweńskim (Katowice 1977), Nomina actionis we współczesnym języku stoweńskim (Katowice 1987), Gramatyce konfrontatywnej języków stowiańskich. Cz. 1. (współautorem pracy jest Włodzimierz Pianka, Katowice 2000) oraz Budowie stowotwórczej przystówków serbsko-chorwackich na podstawie Stownika Vuka Stefanovića Karadžića (Toruń 1970). Istotny wkład w rozwój slawistyki stanowią także prace leksykograficzne Jubilata. Należą do nich między innymi trzy słowniki słowiańskich aproksymatów: Pułapki leksykalne. Słownik aproksymatów polsko-bułgarskich (1994, współautorki: M. Karpaczeva i Ch. Symeonova), Pułapki leksykalne. Stownik aproksymatów polsko-chorwackich (1998) i Pułapki leksykalne. Stownik aproksymatów polsko-stoweńskich (1999). Zarówno polskim słowenistom, jak i słoweńskim polonistom dobrze znany jest podręcznik Slovenščina za Poljake. Kurs podstawowy języka słoweńskiego, który Emil Tokarz wydał w roku 1980 wraz z Tone Pretnarem. Oprócz wspomnianych monografii i słowników Jubilat opublikował ponad siedemdziesiąt prac, wśród których są artykuły naukowe, recenzje i sprawozdania; zredagował dwanaście tematycznych zbiorów artykułów, poświęconych językom, literaturom i kulturom słowiańskim. Wraz z żoną, prof. zw. dr. hab. Bożeną Pikalą-Tokarz, opublikował thumaczenia dramatów słoweńskich: Marcin Żmija. Adaptacja sceniczna w 8 scenach $z$ wprowadzeniem (1977, I. Cankar, J. Povše) i Przeżyć swój los (1978, J. Povše).

Emil Tokarz był redaktorem serii Językoznawstwo Stowiańskie in Językoznawstwo Neofilologiczne (Wydawnictwo Naukowe Uniwersytetu Śląskiego, w skrócie UŚ), redaktorem naukowym prac językoznawczych w Wydawnictwie Naukowym Akademii Techniczno-Humanistycznej w Bielsko-Białej oraz redaktorem naczelnym tegoż wydawnictwa. Do chwili obecnej jest jednym z redaktorów międzynarodowej serii wydawniczej Zora, wydawanej przez Uniwersytet $\mathrm{w}$ Mariborze, członkiem rad programowych wielu czasopism językoznawczych i stowarzyszeń językoznawczych (Polskie Towarzystwo Językoznawcze, Slavistično društvo Slovenije, Rada Językoznawcza Polskiej Akademii Nauk - oddział w Katowicach, Towarzystwo Miłośników Języka Polskiego i Towarzystwo Naukowe w Toruniu).

Jako dydaktyk Emil Tokarz specjalizował się w prowadzeniu przedmiotów z dziedziny językoznawstwa ogólnego i słowiańskiego (w tym słoweńskiego), języka staro- cerkiewno-słowiańskiego oraz słowiańskiej (i słoweńskiej) kultury i cywilizacji. Objął swą opieką promotorską szesnaście doktoratów z dziedziny językoznawstwa, trzysta pięćdziesiąt prac magisterskich z dziedziny filologii słowiańskiej i pedagogiki oraz dwieście pięćdziesiąt licencjackich prac dyplomowych (na Uniwersytecie Śląskim i w Akademii Techniczno-Humanistycznej w Bielsku-Białej). Był także promotorem stu sześćdziesięciu prac na podyplomowych studiach logopedii i neurologopedii obu uczelni. Był recenzentem w trzynastu przewodach doktorskich, dziesięciu habilitacyjnych i w dwunastu przewodach profesorskich. Koordynował cztery projekty naukowe; w piątym, zatytułowanym Slang Master Slovenian Language and Literature Postgraduate Programme, był jednym z głównych wykonawców. Zrecenzował sześć projek- 
tów badawczych w Polsce i dwa w Słowenii. Był także recenzentem dwudziestu dwu monografii naukowych. Pełnił funkcje w kolegiach uniwersyteckich (był między innymi członkiem Senatu Uniwersytetu Śląskiego i członkiem Senatu Akademii Techniczno-Humanistycznej w Bielsku-Białej).

Emil Tokarz jest znany w świecie jako wielki przyjaciel Słowenii oraz aktywny promotor słoweńskiego języka i kultury. Wspólnie z małżonką ustanowił lektoraty języka słoweńskiego na uniwersytetach w Toruniu, Poznaniu i Gdańsku oraz przyczynił się do ustanowienia studiów słowenistycznych na Uniwersytecie Śląskim i w Akademii Techniczno-Humanistycznej w Bielsku-Białej. Razem założyli także Towarzystwo Polsko-Słoweńskie. Zachęcili wiele roczników studentów i studentek do studiów słowenistycznych; niemało z tych osób podąża ich drogą i zajmuje się językiem słoweńskim zawodowo - są naukowcami, tłumaczami, działaczami na polu kultury. Dom Emila i Bożeny Tokarzów zawsze był zawsze otwarty dla Słoweńców. Ich nazwisko jest dobrze znane w Słowenii, bowiem wielu Słoweńców, zapytanych, czy znają kogoś z Polski, wymienia właśnie nazwisko państwa Tokarzy. Swą aktywnością zasłużyli na zaszczytne miano ambasadorów słoweńskiej literatury, kultury i języka w Polsce, Europie i na świecie. Ich zasługi w zakresie krzewienia kultury słoweńskiej na świecie i budowania mostów między kulturą i literaturą polską i słoweńską zostały docenione, czego wyrazem stało się przyznanie w 2007 roku prestiżowej międzynarodowej nagrody im. Pretnara ${ }^{1}$. Emil Tokarz otrzymał w roku 2012 odznaczenie państwowe Republiki Słowenii „Ambasador kultur słowiańskich”, zaś w roku 2013 został odznaczony „Złotym znaczkiem” - nagrodą, którą Uniwersytet w Lublanie przyznaje za wyjątkowe zasługi na polu działalności naukowej, pedagogicznej i artystycznej. Emil Tokarz współpracuje z przedstawicielami świata dyplomacji oraz nauki państw środkowoeuropejskich (zwłaszcza słoweńskimi i chorwackimi). Jako profesor wizytujący wykładał na uczelniach w Lublanie, Mariborze, Koprze, Zagrzebiu, Zadarze, Dubrowniku, Wiedniu, Klagenfurcie i Eisenstadt.

Współpracownicy Emila Tokarza, jego byli studenci i przyjaciele wydali z okazji jego siedemdziesiątych urodzin księgę jubileuszową pod redakcją dr. Mateusza Warchała. Tytuł księgi - W podróży za stowem... (Na poti za besedo...) nawiązuje do charakteru Jubilata i jego intensywnego życia slawisty.

${ }^{1}$ Nagroda, którą od roku 2004 przyznaje Związek pisarzy Velenika i Festiwal, noszący nazwę Herbersteinsko srečanje književnikov (Spotkanie literatów im. Herbersteina), wzięła swą nazwę od nazwiska dr. Tone Pretnara (1945-1992), który był przyjacielem małżeństwa Tokarzów i który swoje życie zakończył w Sosnowcu, gdzie jako lektor wykładał język słoweński pierwszej generacji polskich słowenistów. 


\section{CURRICULUM VITAE}

\section{Emil Franciszek TOKARZ}

ur. 06.10.1944 w Chodorowie (woj. lwowskie) syn Józefa i Stefanii z domu Buczyńskiej

obywatelstwo polskie

\section{2. studia wyższe}

- filologia słowiańska, Wydział Filologiczny, Uniwersytet Jagielloński (1963-1968) rok ukończenia: 30.05.1968 r. promotor: prof. dr hab. S. Urbańczyk, rec. prof. dr hab. F. Sławski.

- studia podyplomowe, filologia słoweńska, Filozofska fakulteta. Univerza v Ljubljani (01.10.1969-30.06.1970), Słowenia, mentor: prof. dr Jože Toporišič.

- studia III cyklu, językoznawstwo ogólne i informatyka, językoznawstwo romańskie, Département de Linguistique et Informatique, UER des Lettres, Université B. Pascal, Clermont-Ferrand, Francja (od 01.10.1984-30.06.1988).

\section{3. doktorat}

Konstrukcje parataktyczne w języku stoweńskim promotor: prof. dr hab. Leszek Moszyński recenzenci: prof. dr hab. Wacław Cimochowski (UMK) prof. dr hab. Leszek Bednarczuk (WSP Kraków) Uniwersytet Mikołaja Kopernika w Toruniu, Wydział Humanistyczny, 09.01.1973 r.

\section{4. habilitacja}

\section{Nomina actionis we wspótczesnym języku stoweńskim}

Wyższa Szkoła Pedagogiczna w Opolu, Wydział Humanistyczny

recenzenci: prof. zw. dr. Martina Orožen (Univerza v Ljubljani), prof. zw. dr hab. Antoni Furdal (Uniwersytet Wrocławski), prof. zw. dr hab. Marian Jurkowski (UW).

data kolokwium: 11.06.1987 r.

data zatwierdzenia: $26.10 .1987 \mathrm{r}$.

\section{5. tytuł naukowy profesora}

22 października $1998 \mathrm{r}$.

Warszawa. Prezydent RP.

6. prof. zwyczajna w Uniwersytecie Śląskim

01.11.2000 r. Minister Edukacji Narodowej. Warszawa.

7. prof. zwyczajna w Akademii Techniczno-Humanistycznej

01.07.2002 r. Minister Edukacji Narodowej. Warszawa.

\section{8. zatrudnienie}

- 01.09.1962-31.09.1963 - Szkoła Podstawowa w Jankowicach Wlk. - nauczyciel.

- 01.10.1963-30.05.1968 - Uniwersytet Jagielloński - student.

- 01.10.1968-30.09.1969 - Uniwersytet M. Kopernika w Toruniu, Katedra Filologii Słowiańskiej - asystent.

- 01.10.1969-30.09.1969 - Uniwersytet M. Kopernika w Toruniu, Katedra Filologii Słowiańskiej - st. asystent. 
- 01.10.1968-01.02.1973 - Uniwersytet M. Kopernika w Toruniu, Katedra Filologii Słowiańskiej - adiunkt.

- 01.02.1973-26.10.1987 - Uniwersytet Śląski w Katowicach, Katedra Językoznawstwa Ogólnego, Katedra Filologii Słowiańskiej - adiunkt.

- 26.10.1978-01.10.1993 - Uniwersytet Śląski w Katowicach, Katedra Filologii Słowiańskiej, Instytut Filologii Słowiańskiej - docent.

- 01.10.1993-01.11.1998 - Uniwersytet Śląski w Katowicach, Instytut Filologii Słowiańskiej, Instytut Pedagogiki, Podyplomowe Studia Logopedii i Glottodydaktyki - dr hab. prof. UŚ.

- 01.11.1998-01.11.2000 - Uniwersytet Śląski w Katowicach, Instytut Filologii Słowiańskiej, Instytut Pedagogiki, Podyplomowe Studia Logopedii i Glottodydaktyki - profesor nadzwyczajny.

- 01.11.2000-01.07.2002 - Uniwersytet Śląski w Katowicach, Instytut Filologii Słowiańskiej, Instytut Pedagogiki, Podyplomowe Studia Logopedii i Glottodydaktyki - profesor nadzwyczajny, profesor zwyczajny.

- 01.07.2002 - Akademia Techniczno-Humanistyczna, Katedra Studiów Środkowoeuropejskich - profesor zwyczajny.

- 01.03.2009 - Akademia Techniczno-Humanistyczna, Wydział Humanistyczno-Społeczny, Podyplomowe Studiu Neurologopedii - profesor zwyczajny.

- 01.03.2009 - Akademia Techniczno-Humanistyczna, Wydział Humanistyczno-Społeczny, Podyplomowe Studia Logopedii z Komunikacją Alternatywną - profesor zwyczajny.

- 01.10.2010 - Akademia Techniczno-Humanistyczna, Katedra Anglistyki - profesor zwyczajny.

- 01.10.2013 - Akademia Techniczno-Humanistyczna, Katedra Anglistyki, Zakład Translacji i Teorii Literatury - profesor zwyczajny.

\section{BIBLIOGRAFIA}

Prof. zw. dr hab. Emil Tokarz

\section{Dzialalność naUkOWa}

1. Wyniki badań własnych i zespołowych - publikacje książkowe i artykuły w kraju i za granicą

\section{A. Druki zwarte (książki, monografie)}

1. Składnia zdań złożonych wspótrzędnie w języku słoweńskim. Prace naukowe Uniwersytetu Śląskiego w Katowicach nr 152. Wyd. UŚ Katowice 1977, ss. 67.

2. Budowa słowotwórcza przysłówków serbsko-chorwackich na podstawie Słownika Vuka Stefanovića Karadžića. Zeszyty Naukowe UMK, z. 38. Filologia Polska. Toruń 1970, s. 192-222.

3. Nomina actionis we współczesnym języku słoweńskim. Prace naukowe Uniwersytetu Śląskiego w Katowicach nr 864. Wyd. UŚ. Katowice 1987, ss. 100.

4. Pułapki leksykalne. Stownik aproksymatów polsko-bułgarskich. Red. nauk. E. Tokarz (współautorki: M. Karpaczewa i Ch. Symeonowa). Wyd. Śląsk. Katowice 1994, ss. 708.

5. Pułapki leksykalne. Słownik aproksymatów polsko-chorwackich. Wyd. Śląsk. Katowice 1998, ss. 381. 
6. Utopia w językach, literaturach i kulturach Słowian. T. I. Ze świadomości utopijnej w refleksji językowej. Red. E. Tokarz. Wyd. UŚ. Katowice 1997, ss. 122.

7. Język wobec przemian kultury. Red. E. Tokarz. Wyd. UŚ. Katowice 1997, ss. 144.

8. Gramatyka konfrontatywna języków stowiańskich. T. I. Red. E. Tokarz. Wyd. Śląsk. Katowice 2000, ss. 306 (współautorstwo całości z W. Pianką, Tom I. autorstwa W. Pianki).

9. Pułapki leksykalne. Stownik aproksymatów polsko-stoweńskich. Wyd. Śląsk. Katowice 1999, ss. 597.

10. Mały słownik polsko-macedoński i macedońsko-polski. Wyd. Śląsk. Katowice 2001, ss. 161 (współautor: D. Stefanija).

11. Stownik chorwacko-polski. Cz. I. (A-O). Wyd. Śląsk. Katowice 2001, ss. 458.

\section{B. Podręczniki, skrypty}

1. Slovenščina za Poljake. Kurs podstawowy języka stoweńskiego. Wyd. UŚ. Katowice 1980, ss. 267 (współautor: Tone Pretnar).

2. Slang Master Slovenian Language and Literature Postgraduate Programme. (Uniwersytety w Mariborze, Klagenfurcie, Trieście, Grazu, Budapeszcie i Akademia Techniczno-Humanistyczna). Program Socrates 60869-IC-1-2004-1-SI-ERASMUSPROGUC-5. Maribor 2007, ss. $141+$ CD.

\section{Studia, rozprawy, artykuly}

1. Gradacijsko priredje v slovenskem knjižnem jeziku. Jezik in slovstvo $18, \mathrm{nr} 7 / 8$. Ljubljana 1973, s. 269-275.

2. Protivno priredje v slovenskem knjižnem jeziku. Slavistična revija 21, nr 4. Ljubljana 1973, s. 465-471.

3. Zdania parataktycznie złożone $w$ języku słoweńskim - projekt binarnej klasyfikacji. Sprawozdania Towarzystwa Naukowego w Toruniu, z. 26. Warszawa - Poznań 1974, s. $87-89$.

4. Sintaktične funkcije pri nomina actionis v sodobni slovenščini. Jezik in slovstvo 20, nr 4. Ljubljana 1975, s. 106-112.

5. Transpozicija semantičnih glagola pri nomina actionis. Slavistična revija 35. Ljubljana 1987, s. $272-279$.

6. Zagadnienia łączliwości nominów actionis we współczesnym języku słoweńskim. Obdobja 8. Ljubljana 1988, s. 367-373.

7. Zagadnienia nominalizacji na przykładzie języków serbsko-chorwackiego i słoweńskiego. [W:] Studia z języków i literatur narodów stowiańskich. Tendencje rozwojowe. Red. B. Czapik i E. Tokarz. Wyd. UŚ. Katowice 1991, s. 101-104.

8. Kriza zavesti ali jezika? (na hrvatskem gradivu). [W:] Nemzetközi Szlavisztikai Napok 4. Szombathely 1991, s. 71-75.

9. Kryzys świadomości czy języka? (Na materiale słoweńskim). [W:] Kryzys tożsamości. Slavica. Red. B. Czapik i E. Tokarz. Wyd. UŚ. Katowice 1992, s. 97-103.

10. Mit wspólnoty Słowian południowych i jego konsekwencje (na przykładzie narodów dawnej Jugosławii). [W:] Rozpad mitu i języka? Red. B. Czapik. Prace Naukowe Uniwersytetu Śląskiego nr 1324. Wyd. UŚ. Katowice 1992, s. 82-87.

11. Słoweńskie przekłady literatury polskiej. [W:] Przekład artystyczny. T. III. Tłumaczenia literatury polskiej na języki obce. Red. P. Fast. Katowice 1992, s. 69-76. 
12. Škrabčevi stiki s poljsko kulturo. [W:] Škrabčeva misel I. Zbornik s simpozija '94. Red. Z. Jan, J. Toporišič. Nova Gorica 1995, s. 151-159.

13. Kriza zavesti ali jezika pri Slovencih? Primorska srečanja: revija za družboslovje in kulturo 20, 183/84 (1996). Nova Gorica-Koper-Idrija: Društvo sociologov in politologov severnoprimorskih občin, s. 566-568.

14. Utopijne teorie językowe u Słowian południowych. [W:] Utopia w językach, literaturach i kulturach Stowian. T. I. Ze świadomości utopijnej w refleksji językowej. Red. E. Tokarz. Wyd. UŚ. Katowice 1997, s. 97-104.

15. Nowe języki dawnej Jugosławii. Slava. Debatni list 2. Ljubljana 1996/97, s. 127-134.

16. Zmierzch Jugosławii - nowe czasy, nowe języki. [W:] Tematy. Księga jubileuszowa w 70. rocznicę urodzin Profesora Leszka Moszyńskiego. Red. K. Szczęśniak, H. Wątróbska. Wyd. Uniwersytetu Gdańskiego, Gdańsk 1998, s. 426-431.

17. Nova vremena novi jezici. Radovi zavoda za slavensku filologiju, zv. 32. Zagreb 1998, s. 209-214.

18. Mikrojęzyki słowiańskie - problemy badawcze językoznawstwa porównawczego. [W:] Nowe czasy, nowe języki. Red. E. Jędrzejko. Wyd. UŚ. Katowice 1998, s. 240-249.

19. Rusini dawnej Jugosławii. [W:] Studia lingwistyczne ofiarowane Profesorowi Kazimierzowi Polańskiemu na 70-lecie Jego urodzin. Red. W. Banyś, L. Bednarczuk, S. Karolak. Wyd. UŚ. Katowice 1999, s. 421-424.

20. Współczesne standardy językowe dialektów sztokawskich. [W:] Języki słowiańskie dziś. Nowe akty. Nowe spojrzenia. Księga pamiątkowa poświęcona Profesorowi Michałowi Blicharskiemu. Red. H. Fontański, E. Straś. Wyd. UŚ. Katowice 2001, s. $19-25$.

21. Pregled na gramatikata na polskiot jazik. [W:] Słownik polsko-macedoński i macedońsko-polski (współautor: D. Stefanija). Wyd. Śląsk. Katowice 2001, s. 9-18.

22. Powstawania nowych standardów językowych u Słowian. [W:] Słowiańszczyzna w kontekście przemian Europy końca XX wieku (język - tradycja - kultura). Red. E. Tokarz. Wyd. Śląsk. Katowice 2001, s. 157-164.

23. Tzw. wyrazy zdradliwe w języku polskim, słowackim i słoweńskim. [W:] Zborník Filozofickej fakulty Univerzity Komenského. Philologica LIII. Red. M. Pančiková. Bratislava 2001, s. 189-194.

24. Nowosztokawskie standardy językowe. [W:] Nadzieje i zagrożenia slawistyki $i$ komparatystyki u progu nowego stulecia (Ksiega dedykowana prof. dr hab. Halinie Janaszek-Ivaničkovej). Red. J. Zarek. Wyd. UŚ. Katowice 2002, s. 490-494.

25. Gradišciańscy Chorwaci w kontekście wielokulturowości Unii Europejskiej. [W:] Studia Slavica Savariensia. Red. K. Gadányi. Szombathely 2002, s. 261-265 (współautor: A. Ślęzak).

26. Unijna wielokulturowość na przykładzie Chotrwatów Gradišciańskich. [W:] Język $i$ tradycje Stowian. Red. E. Tokarz. Wyd. UŚ. Katowice 2003, s. 310-314 (współautor: A. Ślęzak).

27. Język słoweński w kontekście unijnej wielokulturowości. [W:] Śląskie studia lingwistyczne. Red. K. Kleszczowa, J. Sobczykowa. Wyd. UŚ. Katowive 2003, s. 309-313.

28. Slovenski jezik in kultura v kontekstu večkulturnosti Evropske unije. [W:] Slovenski knjižnji jezik - aktualna vprašanja in zgodovinske izkušnje. (Obdobja 20.) Red. A. Vidovič-Muha. Wyd. Univerza v Ljubljani FF. Ljubljana 2003, s. 173-176 (wspó1autorka: B. Tokarz). 
29. Zróżnicowanie językowe Słowian w kontekście integracji Unii Europejskiej. [W:] Idee wspólnotowe Stowiańszczyzny. Red. A. W. Mikołajczak, W. Szulc, B. Zieliński. Wyd. Naukowe UAM. Poznań 2004, s. 199-204.

30. Zróżnicowanie południowosłowiańskich standardów językowych. [W:] Knjižno in narečno besedotvorje slovenskega jezika. (Zora 32). Red. M. Jesenšek. Wyd. Slavistično društvo Maribor. Maribor 2005, s. 449-455.

31. Baudouin de Courtenay in njegovo delo v Škrabčevih delih. [W:] Škrabčeva misel V. Zbornik s simpozija 2005. Red. J. Toporišič. Nova Gorica 2006, s. 15-19.

32. Konceptualizacja MAKROWYDARZENIA na przykładzie fragmentów tekstów angielskich tekstów internetowych. [W:] Jezikovna predanost. Red. M. Jesenšek. (Zora 44). Wyd. Slavistično društvo Maribor, SAZU Ljubljana. Maribor 2006, s. 309-322 (współautorka: D. Chłopek).

33. Językowy świat współczesnych Słowian. [W:] Świat Słowian 1. Red. E. Tokarz. Wyd. Naukowe ATH. Bielsko-Biała 2006, s. 290-295.

34. Świat południosłowiańskich diaspor na przykładzie Molizańskich Słowian. [W:] Świat Techniki i Humanistyki. Prace Naukowe Akademii Techniczno-Humanistycznej nr 1. Red. E. Tokarz. Wyd. Naukowe ATH. Bielsko-Biała 2007, s. 213-216 (współautor: K. Feruga).

35. Tzw. wyrazy zdradliwe w językach polskim i słoweńskim. [W:] Besedje slovenskega jezika. Red. M. Jesenšek. (Zora 50). Wyd. Slavistično društvo Maribor. Maribor 2007, s. $356-360$.

36. V mreži možnih svetov. Rp. Lirikon 21. Revija za poezijo XXI st. nr 14/15/16. Red. I. Stropnik, Z. Pevec. Velenje 2007, s. 386-394 (współautorka: B. Tokarz).

37. Zagubione w historii diaspory słowiańskie. [W:] Opowiedzieć historię. Red. B. Gontarz, M. Krakowiak. Wyd. UŚ, Katowice 2009, s. 446-455 (współautor: K. Feruga).

38. Językowy świat małych ojczyzn czyli słowiańskie pogranicza językowe. Slavia centralis, let. II, 2. Maribor 2009, s. 89-93.

39. Słowa w czasie i tradycji (na przykładzie zróżnicowania językowego Słowian. [W:] Przez Stowo - w stowach - o stowach. Red. T. Borutko, A. Węgrzyniak, A. Matuszek. Wyd. Naukowe ATH, Bielsko-Biała 2009, s. 221-227.

40. Internet Monolingual Lexicons of the English Language and Meaning Construction. [W:] Izzivi sodobnega slovenskega slovaropisja. (Zora 75). Red. M. Jesenšek. Wyd. Mednarodna založba Oddelka za slovanske jezike in književnosti, Filozofska fakulteta. Bielsko-Biała, Budapest, Kansas, Maribor, Praha 2011, s. 146-163 (współautorka: D. Chłopek).

41. Typowe zdania angielskie wyrażone w języku polskim. [W:] Konfrontacje składniowe. Nowe fakty, nowe idee. Red. J. Lubocha-Kruglik, M. Borek. Wyd. US. Katowice 2013, s. 70-78 (współautorka: D. Chłopek).

42. Lexical Hibrids in Specialised Dictionaries from Interferential Perspective. [W:] Specialised Lexicography. Ed. Vida Jesednšek. Wyd. De Gruyter. Berlin/Boston 2013, s. 73-79 (współautor: M. Warchał).

43. Perception of English Prepositions and Particles by Polish and Slovenian Users of the English Language [W:] Slovenski jezik na stičištu več kultur. (Zora 102). Red. M. Jesenšek. Wyd. Mednarodna založba Oddelka za slovanske jezike in književnosti, Filozofska fakulteta. Maribor 2014, s. 287-311 (współautorka: D. Chłopek).

44. Doživeti slovenskost [W:] Prihodnost v slovenskem jeziku, literaturi in kulturi. Red. H. Tivadar. Wyd. Znanstvena založba Filozofske fakultete. Ljubljana 2014, s. 133-138 (współautorka: B. Tokarz). 
45. Język słoweński wobec integracji europejskiej. [W:] Jeziki, literature in kulture v stiku. Red. M. Jesenšek. Wyd. Univerza v Mariboru. Maribor 2014, s. 77-84.

\section{Recenzje, prace popularne, inne}

1. IV Seminarium języka słoweńskiego, literatury i kultury słoweńskiej. Poradnik Językowy 3 (269). Warszawa 1969, s. 212-214.

2. R. Štefanova, W. Łaciak: Učbenik poljskega jezika. Ljubljana 1969, ss. 276. Poradnik Językowy 3 (278). Warszawa 1970, s. 183-184.

3. Poljska slovenistika v okviru poljsko-slovenskih stikov. [W:] Ramovšev zbornik. Slavistična revija 42, nr 2-3. (Obdobja 12). Ljubljana 1994, s. 393-399.

4. Macedonistyka polska na tle kontaktów polsko-macedońskich. [W:] Naučna diskusija na XXVIII meg'unaroden seminar za makedonski jazik, literatura i kultura. Skopje 1996, s. 407-410.

5. Pasje slawistyczne profesora Leszka Moszyńskiego czyli toruńska slawistyka i polonistyka przełomu lat sześćdziesiątych i siedemdziesiątych. [W:] Polonistyka toruńska Uniwersytetowi w 50. rocznice utworzenia UMK. Językoznawstwo. Red. K. Kallas. Toruń 1995, s. 25-30.

6. Prof. dr hab. Kazimierz Polański - twórca śląskiej slawistyki. [W:] Utopia w językach, literaturach i kulturach Stowian. T. I. Ze świadomości utopijnej w refleksji językowej. Red. E. Tokarz. Wyd. UŚ. Katowice 1997, s. 7-9.

7. Wstęp. [W:] Utopia w językach, literaturach i kulturach Stowian. T. I. Ze świadomości utopijnej w refleksji językowej. Red. E. Tokarz. Wyd. UŚ. Katowice 1997, s. 43.

8. Przedmowa. [W:] Język wobec przemian kultury. Red. E. Tokarz. Wyd. UŚ. Katowice 1997, s. 7-8.

9. Bibliografia prac prof. dra hab. Kazimierza Polańskiego. [W:] Utopia w językach, literaturach i kulturach Stowian. T. I. Ze świadomości utopijnej w refleksji językowej. Red. E. Tokarz. Wyd. UŚ. Katowice 1997, s. 10-21.

10. Pani Profesor dr hab. Halina Janaszek-Ivaničková. [W:] Nadzieje i zagrożenia slawistyki i komparatystyki u progu nowego stulecia (Ksiega dedykowana prof. dr hab. Halinie Janaszek-Ivaničkovej). Red. J. Zarek. Wyd. UŚ. Katowice 2001, s. 5-11.

11. Kroatistika na Šleskom sveučilištu. [W:] Zbornik zagrebačke slavističke škole. Red. M. Samardžija. Filozofski fakultet. Zagreb 2002, s. 158-164 (współautorka: B. Tokarz).

12. Nota biograficzna profesora Mieczysława Basaja. [W:] Język i tradycje Stowian. Red. E. Tokarz. Wyd. UŚ. Katowice 2003, s. 5-10.

13. Sodobna slovenistika na Poljskem. [W:] Perspektive slovenistike ob vključevanju v Evropsko zvezo. Red. M. Jesenšek. Wyd. Slavistično društvo Slovenije. Ljubljana 2003, s. 234-236.

14. Zaslužna profesorica doktorica Zinka Zorko, izredna članica Slovenske akademije znanosti in umetnosti. [W:] Diahronija in sinhronija $v$ dialektoloških raziskavah. (Zora 41.) Red. M. Koletnik, V. Smole. Wyd. Slavistično društvo Maribor. Maribor 2006, s. 449-455.

15. Marko Jesenšek: The Slovene Language in the Alpine and Pannonian Language Area: The History of the Slovene Language. Wyd. Universitas. Kraków 2005, 365 str. [W:] Časopis za zgodovino in narodopisje r. 78, z. 1. Ljubljana 2007, s. 115-118.

16. Macedonistyka polska na tle kontaktów polsko-macedońskich. [W:] Slavistički studii. Nr. 13. Univerzitet sv. Kiril i Metodij. Filološki fakultet Blaže Koneski. Skopje 2009, s. $179-182$. 
17. Kazimierz Polański (1929-2009). [W:] Świat Stowian II. Wyd. Naukowe ATH. Bielsko-Biała 2009, s. 9-12.

18. Z Tinką przez słoweńskość. [W:] Globinska moč besede. (Zora 80). Red. M. Jesenšek. Wyd. Mednarodna založba Oddelka za slovanske jezike in književnosti, Filozofska fakulteta. Bielsko-Biała, Budapest, Kansas, Maribor, Praha 2011, s. 20-25.

19. Polska slawistyka i jej problemy w świecie. Novaja rusistika. Brno 2012, s. 41-46 (współautorka: B. Tokarz).

20. B. Pikala-Tokarz, E. Tokarz: Franc Miklošič i Polacy. [W:] Miklošičeva monografija. Ob dvestoletnici rojstva Franca Miklošiča. Red. M. Jesenšek. Ljutomer 2013, s. 91-100.

21. B. Pikala-Tokarz, E. Tokarz: Komunikacja międzykulturowa jako przyszłość slawistyki, Novaja rusistika, Supplement. Brno 2013, s. 3-11 (współautorka: B. Tokarz).

22. B. Pogorelec: Zgodovina slovenskega knjižnega jezika. Jezikovni spisi I. Red. K. Ahačič. Wyd. ZRC. Ljubljana 2011, ss. 499; B. Pogorelec: Zgodovina slovenskega knjižnega jezika. Jezikovni spisi II. Red. K. M. Smolej. Wyd. ZRC. Ljubljana 2011, ss. 362. [W:] Świat Stowian III. Red. K. Feruga, L. Pavera. Wyd. ATH. Bielsko-Biała 2014, s. 331-334.

\section{E. Redakcja prac zbiorowych}

1. Redaktor naukowy serii: Językoznawstwo Stowiańskie w Wydawnictwie Uniwersytetu Śląskiego od 1.10.1996-1.10.2002.

2. Redaktor naukowy serii: Jezzkoznawstwo Neofilologiczne w Wydawnictwie Uniwersytetu Śląskiego od 17.03.1998 do 16.11.1999.

3. Redaktor naukowy prac językoznawczych Wydziału Humanistyczno-Społecznego Wydawnictwa Akademii Techniczno-Humanistycznej w Bielsku Białej od 01.10.2002.

4. Redaktor naczelny Wydawnictwa Naukowego Akademii Techniczno-Humanistycznej w Bielsku Białej od 01.10.2006.

5. Studia z języków i literatur narodów stowiańskich: tendencje rozwojowe - Red. B. Czapik, E. Tokarz. Wyd. UŚ. Katowice 1991.

6. Kryzys tożsamości. Slavica. Red. B. Czapik, E. Tokarz. Wyd. UŚ. Katowice 1992.

7. Pułapki leksykalne. Stownik aproksymatów polsko-bułgarskich. Red. nauk. E. Tokarz (współautorki: M. Karpaczewa i Ch. Symeonowa). Wyd. Śląsk. Katowice 1994.

8. Douwe Fokkema. Red. E. Tokarz, T. Miczka. Wyd. UŚ. Katowice 1995.

9. Utopia w językach, literaturach i kulturach Słowian. T. I. Ze świadomości utopijnej w refleksji językowej. Red. E. Tokarz. Wyd. UŚ. Katowice 1997, ss. 122.

10. Język wobec przemian kultury. Red. E. Tokarz. Wyd. UŚ. Katowice 1997, ss. 144.

11. W kręgu Kultury Stowian. Księga pamiątkowa poświęcona 45-leciu pracy naukowo-dydaktycznej Pani Profesor dr hab. Henryki Czajki. Red. E. Tokarz. Wyd. UŚ, Katowice 1999, ss. 257.

12. W. Pianka, E. Tokarz: Gramatyka kontrastywna języków słowiańskich. T. I Red. E. Tokarz. Wyd. Śląsk. Katowice 1999, ss. 306.

13. Stowiańszczyzna $w$ kontekście przemian Europy końca XX wieku (język-tradycja - kultura). Red. E. Tokarz. Wyd. Śląsk. Wyd. Śląsk. Katowice 2001, ss. 323.

14. Język i tradycje Stowian. Red. E. Tokarz. Wyd. UŚ. Katowice 2003, ss. 480.

15. Świat Słowian I. Red. E. Tokarz. Wyd. ATH. Bielsko-Biała 2006, ss. 295. 
16. Świat Techniki i Humanistyki. Prace Naukowe Akademii Techniczno-Humanistycznej nr 1. Red. E. Tokarz. Wyd. Naukowe ATH. Bielsko-Biała 2007, s. 401.

\section{Thumaczenia}

1. Cankar, J. Povše: Marcin Żmija. Adaptacja sceniczna w 8 scenach z wprowadzeniem. Warszawa 1977 (tłumaczenie dramatu wspólnie z B. Pikalą-Tokarz).

2. J. Povše: Przeżyć swój los. Warszawa 1978 (tłumaczenie dramatu wspólnie z B. Pikalą-Tokarz).

\section{Uczestnictwo w międzynarodowych konferencjach, kongresach i sympozjach nauko- wych}

1. Vprašanje vezljivosti pri nomina actionis v sodobni slovenščini. Mednarodni simpozij v Ljubljani Sodobni slovenski jezik, književnost i kultura. (1-3.07.1986).

2. Peryferie językowe. Konferencja Język polski dawnych pólnocno-wschodnich Kresów Rzeczypospolitej. W 10 rocznice śmierci prof. Haliny Turskiej. Torun 24-25.09.1988.

3. Stoweńskie i serbskochorwackie nomina actionis. Konference Synchronni konfrontace slovanských jazykü. Olomouc 23-24.03.1989.

4. Kulturne veze sjevernih i jużih Slavena. Konferencja Slaveni-jezik, literatura $i$ kultura. Banjaluka 22-23.03.1990.

5. Poljska slovenistika v okviru poljsko-slovenskih stikov. Mednarodni simpozij v Ljubljani. Obdobje znanosti o jeziku, književnosti in kulturi v počastitev stoletnice rojstva Frana Ramovša. (27-29.06.1990).

6. Kriza zavesti ali jezika: (na hrvaškem gradivu). Slavistične dneve. Szombathely 16-18.05.1990.

7. Kryzys świadomości czy języka? (Na materiale słoweńskim). Międzynarodowa konferencja Kryzys tożsamości. Katowice 1991.

8. Słoweńskie przekłady literatury polskiej. Międzynarodowa konferencja Przekład artystyczny. Tlumaczenia literatury polskiej na języki obce. Szczyrk 18-20.02.1991.

9. Mit wspólnoty Stowian poludniowych i jego konsekwencje (na przyktadzie narodów dawnej Jugosławii). Kongres Slawistów w Bratysławie 30.08.-9.09.1993.

10. Škrabčevi stiki s poljsko kulturo. Mednarodni simpozij Škrabčevi dvevi '94. Nova Gorica 11-13.05.1994.

11. Pasje slawistyczne profesora Leszka Moszyńskiego czyli toruńska slawistyka i polonistyka przełomu lat sześćdziesiatych i siedemdziesiatych. Konferencja Polonistyka toruńska Uniwersytetowi. Toruń 14-16.03.1995.

12. Utopijne teorie językowe u Stowian poludniowych. Międzynarodowa konferencja Utopia w językach, literaturach i kulturach Stowian. Katowice 25-27.09.1995.

13. Kriza zavesti ali jezika pri Slovencih v današnjem času. Ljubljana 6.05.1996 r.

14. Slovakistika polska a slovenská kultúra. Międzynarodowa konferencja Zahraniční Slováci a slovakisti v kontexte záujmov SR. Bratislava 10-11.09.1996.

15. Mikrojęzyki słowiańskie - problemy badawcze językoznawstwa porównawczego. Międzynarodowa konferencja Nowe czasy, nowe „języki”, nowe i (stare) problemy. Katowice 21-22.10.1996.

16. Jezik Prešernovih sonetov. Międzynarodowe sympozjum naukowe Prešernovi dnevi v Kranju. Kranj 2-5.02.1999.

17. Międzynarodowa konferencja naukowa Stowacja w obliczu Europy. Cieszyn 31.05. - 2.06.1999. Organizacja i uczestnictwo. 
18. Promocja książki E. Tokarz: Pułapki leksykalne. Słownik aproksymatów polsko-chorwackich. Wyd. Śląsk. Katowice 1999. - Dubrovnik 29.09.1999.

19. Konferencja nt. Študijne stredisko UJOP ZŠ UK. Modra-Bratysława 30.11.1999. Ref. Stowacystyka śląska w kontekście stowacystycznych studiów zagranicznych.

20. Międzynarodowa konferencja Stowiańszczyzna w kontekśsie przemian Europy końca XX wieku. 15.05.2001. Katowice. Ref. Powstawanie nowych standardów językowych u Stowian.

21. Międzynarodowa konferencja Wielokulturowość pogranicza. Cieszyn 19-20.05.2004. Org.: ATH Bielsko-Biała, Stowarzyszenie Solidarność Polsko-Czesko-Słowacka. Ref.: Gradišče - wielokulturowe pogranicze (współautor: A. Ślęzak).

22. Międzynarodowe sympozjum nt. Slovenski jezik v stiku. Slovenščina in njeni uprorabniki v luči Evropske integracije. Koper 20-22.05.2004. Organ. Univerza na Primorskem, Znanstveno-raziskovalno središče Koper, Inštitut za jezikoslovne študije. Ref. Položaj subjektivitete v procesu integracije.

23. Międzynarodowe sympozjum nt. Knjižno in narečno besedotvorje slovenskega jezika. Maribor 10-11.06.2004, organ. Univerza v Mariboru. Oddelek za slovenske jezike in književnosti. Slavistično društvo Maribor. Ref. Diferenciacija južnoslovanskih jezikov (na primeru leksike).

24. Mednarodno literarno srečanje pesnikov, pisateljev in esejistov Vilenica 2004 Kosovel med etiko in poetiko. Lipica, 8-10.09 2004. Org. Oddelek za primerjalno književnost in literarno teorijo, Filozofska fakulteta Univerze v Ljubljani, Slovensko društvo za primerjalno kniževnost, Društvo slovenskih pisateljev. Udział w dyskusji okrągłego stołu.

25. Kongres slawistyczny III jornadas adaluzas de eslavistica. La eslavistica en el inicio del siglo XXI. Granada 22-24.09.2004. Org. Universidad de Granada. Udział w dyskusji okrągłego stołu.

26. Międzynarodowa konferencja Problematyka podmiotowości jednostek i grup spolecznych we wspótczesnej cywilizacji Stowian. Ustroń 29.09-01.10.2004. Org. Instytut Filologii Słowiańskiej UŚ, Międzynarodowa Sieć Naukowa Literatury Słowiańskie po roku 1989 w dialogu z Europą i światem. Wydział Polonistyki UW.

27. Uroczysta inauguracja nowych kierunków studiów: bohemistyki, polonistyki i słowacystyki na Wydziale Filozoficznym Uniwersytetu w Lublanie, Lublana 6-8.10.2004. Org. Uniwersytet w Lublanie. Uczestnictwo w dyskusji okraglego stołu nt. reformy studiów wyższych i współpracy miedzynarodowej. Uczestnictwo w uroczystości nadania tytułu he V. Havlovi, A. Michnikowi i A. Zajcowi.

28. Slovenski slavistični kongres Slovenski jezik in literatura v evropskih globalizacijskih procesih. Nove mesto 8-10.10.2004. Org. Slavistično društvo Slovenije. Uczestnictwo w dyskusji okragłego stołu nt. Metafore mladih in za mlade v luči kognitivnega pomenoslovja.

29. Międzynarodowa konferencja polsko-słoweńska Pogranicza słowiańskie: problemy $i$ wyzwania. Bielsko-Biała 20.10.2004. Org. Univerza na Primorskem. Fakulteta za humanistične študije. Akademia Techniczno-Humanistyczna. Katedra Studiów Środkowoeuropejskich. Katedra Językoznawstwa Ogólnego i Metodologii Badań Humanistycznych. Ref. Stoweńskie pogranicze kulturowe i językowe.

30. Międzynarodowe naukowe sympozjum nt. Slovenska kratka pripovedna proza. Lublana 9-11.12.2004. Org. Oddelek za slovenistiko. FF. Wydział Filologiczny Uniwersytetu w Lublanie. Ref. Język matych form.

31. Dni Kultury Bośni i Hercegowiny. Org. Katedra Filologii Słowiańskiej UMK w Poznaniu. Poznań 21-23.02.2005. Ref. Współczesny język bośniacki. 
32. Polska i Chorwacja w Europie Środkowej. (Integracja europejska w tradycji i w przyszłości). Katedra Językoznawstwa Ogólnego i Metodologii Badań Humanistycznych ATH i Stowarzyszenie „Instytut Południowy”. Bielsko-Biała 11-13.05.2005.

33. Slovenski dialekti v stiku 2. Mednarodni znanstveni sestanek. Org. Univerza na Primorskem, Znanstveno-raziskovalno središče Koper. Slovenija. Koper 6-8.05.2005. Udział w dyskusji okrągłego stołu.

34. 5 Škrabčevi simpozij. Jezikoslovci in njihova dela v Škrabčevih očeh. Org. Frančiškanski samostan Kostanjevica. Slavistično društvo Slovenije. Nova Gorica 19-20.05.2005. Ref. Baudouin de Courtenay in njegovo delo $v$ Škrabčevih očeh.

35. V Forum Oświaty Polonijnej w Bielsku-Białej. Org. Wspólnota Polska. Oddział w Bielsku-Białej, ATH. UŚ, Uniwersytet w Ostrawie. Bielsko-Biała 27-29.05.2005.

36. Perspektive slovenističnega študija na univerzah po svetu. Org. Slovenski znanstveni inštitut na Dunaju. Wiedeń 21.10.2005. Ref. Slovenistika v Tehnično-humanistični akademiji v Bielsko-Biati.

37. Lisbon strategy and competitiveness of the Danube region. Org. Danube Rectors Conference. Maribor 21-23.09.2006. Ref. Slang masters Strategy.

38. Književnost v izobraževanju - cilj, vsebine, metode. Obdobja 25. Metode in zvrsti. Org. Univerza v Ljubjani, FF Oddelek za slavistiko, Center za slovenščino kot drugi/ tuji jezik. Ljubljana 16-18.11.2006. Ref. Kako učiti slovenščino na tujih univerzah.

39. Historia w historii Rosji. Literatura i dokument. Org. Rosyjska Sekcja Kulturoznawcza Koła Naukowego Slawistów ATH. Bielsko-Biała 26.03.2007. Słowo wstępne. Otwarcie konferencji.

40. Besedje slovenskega jezika. Mednarodni znanstveni simpozij. Org. Filozofska fakulteta Univerze v Mariboru. Maribor 18-19.05.2007. Ref.: Tzw. wyrazy zdradliwe w jezyku polskim i stoweńskim.

41. Slovenščina na tujem. Org. Katedra Filologii Słowiańskiej Uniwersytetu w Budapeszcie. Budapest 24.05.2007. Ref.: Primer širitve slovenščine na Poljskem.

42. Konferencja w Koprze. Org.: Univerza na Primorskem. Koper 25-27.05.2007. Ref. Slovenski dialekti na Poljskem.

43. Herbersteinsko srečanje književnikov. Org. Ministrstvo za kulturo Republike Slovenije, Mestna občina Velenje, Velenjska knjižna fundacija, Društvo pisateljev Slovenije. Ref. V mreži mogočnih tokov, otrzymanie Pretnarjeve nagrade 2007 ambasadorjema slovenske književnosti in jezika na Poljskem (wspólnie z prof. B. Tokarz)

44. Forum europejskiej slawistyki południowej na rzecz pokoju i koegzystencji. Org. Katedra Filologii Słowiańskiej UAM. Słubice-Frankfurt n. Odrą, 26-28.06.2007. Ref. Poludniowosłowiańska slawistyka w ATH w Bielsku-Białej. Głos w dyskusjji: Poludniowosłowiańskie specjalizacje - rozwój i zagrożenie.

45. Slang Master Slovenian Language and Literature Postgraduate Programme. Wisła 20-23.09.2007. Org. Akademia Techniczno-Humanistyczna w Bielsku-Białej. Ref. Sprawozdanie z końcowej fazy projektu.

46. Večjezičnost v Evropski zvezi. Międzynarodowa konferencja org. Uniwersytet w Mariborze, ELTE w Budapeszcie, Uniwersytet Karola w Pradze, Akademia Techniczno-Humanistyczna w Bielsku-Białej, Uniwersytet w Kansas. Maribor 13-15.11.2008. Ref. Jezikovni svet malih domovin - slovenska obmejna jezikovna območja.

47. Stowa, stowa, stowa ... refleksje o stowie. Konferencja naukowa org. Instytut Teologiczny im. Św. J. Kantego PAT, Katedra Polonistyki ATH, Bielsko-Biała 24-25.11.2008. Ref. Słowa w czasie i tradycji (na przykładzie zróżnicowania językowego Stowian).

48. Bielski Festiwal Kultury Słowackiej; Książnica Miejska. Bielsko-Biała, 22.10.2009. 
49. Międzynarodowa konferencja Poučevanje slovenščine zunaj meja. Slovenski Znanstveni Inštitut, Wiedeń 18.09.2009. Ref. Slovenščina v novih programih Slang Mastersa.

50. LXVII Zjazd PTJ, Olsztyn 25-26.09.2009.

51. Międzynarodowa konferencja Obdobja 28. Infrastruktura slovenščine in slovenistike. Center za slovenščino. Ljubljana 26-28.11.2009. Ref. Kako uničiti slovenščino na tujem.

52. Międzynarodowa konferencja Literatura i obrazy. Wydział Humanistyczno-Społeczny ATH. Bielsko-Biała 16-17.11.2009.

53. Międzynarodowa Konferencja Naukowa Kobiety i kobiecość w kulturach chrześcijańskiej i mozaizmie. Koło Naukowe Polonistów ATH. Bielsko-Biała. 18.11.2009.

54. Konferencja naukowa Literatura i historia połączona z promocją księgi jubileuszowej Opowiedzieć historię dedykowanej prof. dr. hab. S. Zabierowskiemu. Uniwersytet Śląski Wydział Filologiczny, Katowice 21.01.2010.

55. Warsztaty w ramach projektu norweskiego Nowoczesne narzędzia naukowo-gospodarcze w obszarze srodkowoeuropejskim. Wydział Humanistyczno-Społeczny. Bielsko-Biała 19.01.2010.

56. Miedzynarodowa konferencja naukowa (Neuro)logopedia w teorii i praktyce. Bielsko-Biała 20.03.2010.

57. Dnevi Maksa Pleteršnika Izzivi sodobnega slovenskega slovaropisja. Filozofska fakulteta Univerze v Mariboru. Pišece 13-14.09.2010. Słowenia. Ref.: Internet English Monolingual Lexicons and Meaning Constructions (współautorka: D. Chłopek)

58. Kongres Kultury Województwa Śląskiego 2010. Marszałek Województwa Śląskiego. Katowice 23.09. - 25.09.2010.

59. 1-st International Academic Blues Conference Blues as a Cultural Phenomenon. Wydział Humanistyczno-Społeczny ATH. Bielsko-Biała 7-9.10.2010.

60. Sesja panelowa Odgrzebywanie Witkacego. Wydział Humanistyczno-Społeczny ATH, Stowarzyszenie Centrum Sztuki KONTRAST, Teatr Polski w Bielsku-Białej, Bielsko-Biała 7.10.2010.

61. Miedzynarodowa konferencja naukowa Media - komunikacja - kultura. Wydział Humanistyczno-Społeczny ATH. Bielsko-Biała 22-23.10.2010.

62. 6 Kolloquium zur Lexikographie und Wörterbuchforschung Lexikographie der Fachsprachen print- und digitale Formate, Fachwörterbücher, Datenbanken. Universität Maribor, Maribor 25-28.10.2010. Ref.: Lexical Hibrids in Specialised Dictionaries from Interferential Perspective (współautor: M. Warchał).

63. Międzynarodowe sympozjum 29 Obdobja. Sodobna slovenska književnost (19802010). Univerza v Ljubljani, Ljubljana 11-13.11.2010.

64. Międzynarodowa konferencja Pytanie o wspólnotę. Akademia Techniczno-Humanistyczna, Wydział Humanistyczno-Społeczny, Uniwersytet Jana Pawła II, Instytut Teologiczny, Bielsko-Biała 16-18.11.2010. Ref.: Wspólnota językowa Słowian.

65. Konferencja naukowa Współczesne wymiary Humanizmu. Koło Naukowe Humanistów ATH oraz Koło Teologiczne przy Instytucie Teologicznym Uniwersytetu Jana-Pawła II w Krakowie, Bielsko-Biała 7-8.12.2010.

66. Międzynarodowa konferencja naukowa Edukacyjne konteksty wspomagania rozwoju dziecka. Org. Katedra Pedagogiki i Psychologii ATH. Bielsko-Biała 08.03.2011.

67. Międzynarodowa konferencja naukowa Kosovel in politična resnica poezije. Org. Literarno društvo Slovenije, Slovensko društvo za primerjalno književnost, revija Primerjalna književnost. Ljubljana-Škocja 12-15.03.2011. 
68. Międzynarodowa konferencja naukowa Wczesna edukacja w kontekście zmian. Org. Uniwersytet pedagogiczny im. KEN w Krakowie, Uniwersytet Humanistyczno-Przyrodniczy J. Kochanowskiego w Kielcach. Kraków 28.03.2011.

69. Kongres Języka Polskiego. Org. Rada Języka Polskiego PAN, Katowice 4-6.05.2011.

70. Jubileuszowa konferencja pedagogiczna Dziecko ze specjalnymi potrzebami edukacyjnymi w przedszkolu i szkole. Org. Katedra Pedagogiki i Psychologii ATH. Birlsko-Biała 26.05.2011.

71. XII Beskidzki Festiwal Nauki i Sztuki. Bielsko-Biała 27-28.05.2011.

72. VIII Międzynarodowe Warsztaty tramslatologiczne. Org. Katedra Studiów Środkowoeuropejskich ATH, Bielsko-Biała 28-29.05.2011.

73. Międzynarodowa konferencja naukowa Pamięć zbiorowa i tożsamość w Europie Środkowo-Wschodniej. Kontynuacja-konflikt-zmiana. Org. Katedra Socjologii ATH. Bielsko-Biała 27-28.05.2011. Ref. panel dyskusyjny: Bałkanska pamięć zbiorowa.

74. Studencko-doktorska konferencja naukowa Dotknać Słowiańszczyzny. Języki, literatura i kultura krajów stowiańskich. Wydział Humanistyczno-Społeczny ATH. Bielsko-Biała 30.05.2011.

75. XVIII Ogólnopolska Konferencja Przekładowa Dominanta a przekład. Org. Wydz. Humanistyczno-Społeczny ATH, Zakład Przekladoznawstwa i Portugalistyki Instytutu Filologii Romańskiej UJ. Bielsko-Biała 17-18.06.2011.

76. II Konferencja naukowa neurologopedów Neurologopedia w teorii i praktyce. Org. Studium Podyplomowe Neurologopedii ATH, Bielsko-Biała 04.06.2011.

77. II Konferencja naukowa logopedów. Logopedia w teorii i praktyce. Org. Studium Podyplomowe Logopedii ATH, Bielsko-Biała 11.06.2011.

78. Jubileusz 80 lecia pani prof. dr. M. Orožen. Laudacja Z Tinka przez stoweńskość. Filozofska fakulteta Univerze v Mariboru i Ljubljani, Lublana 12.10.2011.

79. Międzynarodowe sympozjum Bilingwizm indywidualny $i$ zbiorowy. Filozofska fakulteta Univerze v Ljubljani, Ljubljana 20-22.11.2011. Ref. Bilingwalność diaspor słowiańskich.

80. Międzynarodowe sympozjum Slawistyka w świecie - problemy ogólnej jej pozycji, organizacji i metodologii, Universita G. Masarika w Brnie. Brno 27-28.10.2011. Ref. Polska slawistyka i jej problemy w świecie (współautorka: B. Tokarz).

81. Międzynarodowa konferencja Małe miasta. Katedra Literatury i Kultury Polskiej Wydział Humanistyczno-Społeczny ATH i Instytut Teologiczny im. św. Jana Kantego w Bielsku-Białej. Bielsko-Biała 14-15.11.2011.

82. Międzynarodowa konferencja Edukacja małego dziecka. Szanse i zagrożenia. Uniwersytet Śląski. Wydział Etnologii i Nauk o Edukacji w Cieszynie, Univerzita M. Bela w Banskej Bystrici Wydział Pedagogiczny, Wyższa Szkoła Administracji Wydział Nauk Humanistycznych i Studiów Międzynarodowych w Bielsku-Białej, Akademia Techniczno-Humanistyczna, Wydział Humanistyczno-Społeczny katedra Pedagogiki i Psychologii w Bielsku-Białej. Cieszyn 15-16.11.2011.|

83. Konferencja naukowa Wyobraźnia w przekładzie, panel dyskusyjny. Org. UAM. Instytut Filologii Polskiej, Poznań 23-25.04.2012.

84. Międzynarodowa konferencja Lirykon 21, Troedinost poezije-mita-vode. Panorama izvirne in prevodne poezije XXI st. Panel dyskusyjny. Velenje 21-23.06.2012.

85. III Konferencja naukowa logopedów. Logopedia $w$ teorii i praktyce. Org. Studium Podyplomowe Logopedii ATH, Bielsko-Biała 02.07.2012.

86. I międzynarodowa konferencja Humanistic Foreign Lannguage Teaching and Lerning. Uniwersytet Filozofa Konstantina w Nitrze 14-15.09.2012. 
87. II brěnska porada Mezinárodní asociace slavistů a nové postupy v metodologii a metodice filologije. Org. Ústav slavistyky FF MU, Brno 27.09.2012. Ref.: Komunikacja międzykulturowa jako przyszłość slawistyki (współautorka: B. Tokarz).

88. Polsko-słoweńskie konfrontacje filmu krótkometrażowego, panel dyskusyjny. Sosnowiec 27-29.11.2012.

89. Polsko-słoweńskie sympozjum przekładoznawcze Tłumacz jako most między kulturam, panel dyskusyjny. Bielsko-Biała - Katowice 30.11. - 1.12.2012.

90. Międzynarodowa konferencja naukowa 200-letnica rojstva Franca Miklošiča. Org. Filozofska fakulteta UM, Inštitut za slovenski jezik F. Ramovša, Znanstveno raziskovalni center SAZU, Občina Ljutomer, Gimnazija F. Miklošiča Ljutomer, Avstrijski kulturni forum, Ljutomer 18-19.11.2013 (Slovenija). Ref. B. Pikala-Tokarz, E. Tokarz: Franc Miklošič in Poljaki.

3. Wykaz projektów badawczych - grantów (forma uczestnictwa: kierownik główny, wykonawca, wspólwykonawca)

1. Projekt badawczy indywidualny KBN nr 1 H01D 02508 pt. Aproksymacja, czyli pozorne podobieństwa leksykalne $w$ językach zachodnio-południowosłowiańskich $i$ polskim (kierownik i wykonawca projektu) - badania ukończone.

2. Projekt badawczy promotorski KBN nr 1 H01D 00813 pt. Chorwacka leksyka sporto$w a$-rozprawa doktorska R. Bońkowskiego (kierownik projektu)-badania ukończone.

3. Projekt badawczy indywidualny KBN nr 1 H01D 015 pt. Wspótczesne języki standardowe poludniowej Stowiańszczyzny (kierownik projektu) - badania ukończone.

4. Projekt badawczy indywidualny Projekt badawczy promotorski MNiI 0076/ H01/2004/27 pt. Socjolingwistyczne aspekty języka burgemlandzkich Chorwatów rozprawa doktorska A. Ślęzaka (kierownik projektu) badania ukończone.

5. Slang Master Slovenian Language and Literature Postgraduate Programme. (Uniwersytety w Mariborze, Klagenfurcie, Triescie, Grazu, Budapeszcie i Akademia Techniczno-Humanistyczna). Program Socrates 60869-IC-1-2004-1-SI-ERASMUSPROGUC-5. Maribor 2007, ss. $141+$ CD.

\section{Recenzje grantów}

1. Recenzja 6 projektów badawczych KBN.

2. Recenzja 2 projektów badawczych w Słowenii.

\section{Organizacja międzynarodowych konferencji naukowych}

1. Międzynarodowa konferencja Kryzys tożsamości. Instytut Filologii Słowiańskiej UŚ. Katowice 1991.

2. Międzynarodowa konferencja Utopia w językach, literaturach i kulturach Stowian. Instytut Filologii Słowiańskiej UŚ. Katowice 25-27.09.1995.

3. Międzynarodowa konferencja naukowa Słowacja w obliczu Europy. Instytut Filologii Słowiańkiej. Cieszyn 31.05-2.06.1999.

4. Międzynarodowa konferencja Słowiańszczyzna w kontekście przemian Europy końca XX wieku. Katowice. 15.05.2001.

\section{Recenzje wydawnicze}

1. Recenzja wydawnicza monografii W. Gorczycy: Znaczenie i rozumienie w procesie recepcji i tworzenia tekstu obcojęzycznego. Wyd. Rea. Warszawa 1999. 
2. Recenzja wydawnicza monografii J. Koniecznej-Twardzikowej: Gramatyka kontrastywna - gramatyka między stereotypami. Wyd. Śląsk. Katowice 2001.

3. Recenzja wydawnicza pracy zbiorowej Język, literatura i kultura Stowian-dawniej i dziś. Red. B. Zieliński. Wyd. Naukowe UAM. Poznań 2000.

4. Recenzja wydawnicza podręcznika do nauki języka serbskiego Pavle Ćosića: Srpski jezik za strance. Priručnik za lektore i studente srpskog jezika. Tekstovi, vežbanja, igre. Wydawnictwo Naukowe UAM, Poznań 2002.

5. Recenzja wydawnicza monografii Małgorzata Urban pt. Współczesne przymiotniki odrzeczownikowe z wybranymi formantami sufiksalnymi. Torun 2004.

6. Ocena monografii zbiorowej Stowiańskie idee wspólnotowe pod redakcją B. Zielińskiego i W. Szulca. Wydawnictwo Naukowe UAM. Poznań 2004.

7. Recenzja drugiego numeru Folia linguistica rossica zatytułowanego Język-struktura - styl: wspótczesne kierunki badań lingwistycznych por redakcją A. Ginter. Wydawnictwo Naukowe UŁ. Łódź 2004.

8. Recenzja drugiego wydania podręcznika H. Fontańskiego, M. Chomiaka: Gramatyka języka temkowskiego. Katowice 2004.

9. Recenzja monografii zbiorowej Panorama chorwackiej kultury po 1990 roku, pod red. Krystyny Pieniążek-Marković i Bogusława Zielińskiego. Wydawnictwo Naukowe UAM. Poznań 2005.

10. Recenzja monografii M. Bitnioka: Deficyty mowy wynikajace z uszkodzeń obszarów mózgowych. Wyd. UŚ. Katowice 2008

11. M. Chomiak: Język temkowski. Cz. III dla gimnazjum. Wyd. MEN. Warszawa 2008.

12. Recenzja monografii zbiorowej Od Megiserja do elektronske izdaje Pleteršnikovega slovarja. Red. M. Jesenšek, Maribor 2008.

13. Recenzja 12 t. Slawistyki pt. Słowiańszczyzna wczoraj $i$ dziś pod redakcją A. Spagińskiej-Pruszak i N. Wyszogrodzkiej. Wydawnictwo Naukowe UG. Gdańsk 2011.

14. Recenzja monografii L. Hampla: Ptactwo we frazeologii czeskiej i polskiej. Wyd. Naukowe ATH. Bielsko-Biała 2011.

15. Recenzja monografii M. Łabaszczuka: Struktura znaku w ontodiachronii (historii ontogenezy). Wyd. Naukowe ATH. Bielsko-Biała 2011.

16. Recenzja monografii zbiorowej Poglavja iz zgodovine prekmurskega jezika. (Zora 90). Red. M. Jesenšek. Wyd. Mednarodna založba Oddelka za slovanske jezike in književnosti, Filozofska fakulteta. Maribor 2012.

17. Recenzja monografii zbiorowej Poludniowosłowiańskie sąsiedztwo. Slawistyka u komparatystyka dzisiaj. Red. B. Zieliński, E. Szperlik. Wyd. Naukowe UAM. Poznań 2012.

18. Recenzja monografii zbiorowej Topografia tożsamości. T. I. Red. B. Zieliński. Wyd. Naukowe UAM. Poznań 2012.

19. Recenzja monografii zbiorowej Topografia tożsamości. T. II. Red. B. Zieliński. Wyd. Naukowe UAM. Poznań 2012.

20. Recenzja monografii zbiorowej Przestrzenne kody tekstów i narracyjne kody przestrzeni. Red. B. Zieliński. Wyd. Naukowe UAM. Poznań 2013.

21. Recenzja numeru Kultura i estetyka oporu. Mikronarody stowiańskie. „Poznańskie Studia Slawistyczne” 6. Red. K. Pieniążek. Wyd. Naukowe UAM. Poznań 2013.

22. Recenzja numeru Dysydenci, Kontestatorzy, kultura sprzeciwu i współczesność. „Poznańskie Studia Slawistyczne" 6. Red. K. Pieniążek. Wyd. Naukowe UAM. Poznań 2013. 


\section{DZIALALNOŚĆ DYDAKTYCZNA}

\section{Rodzaj prowadzonych zajęć}

wykłady, konwersatoria, ćwiczenia, seminaria magisterskie, seminaria licencjackie, seminaria podyplomowe z zakresu językoznawstwa ogólnego, językoznawstwa słowiańskiego, logopedii, cywilizacji słowiańskich obszarów językowych

\section{Obciążenie dydaktyczne}

wyklady

- gramatyka opisowa języka staro-cerkiewno-słowiańskiego

- wstęp do językoznawstwa ogólnego

- gramatyka opisowa języka słoweńskiego

- gramatyka opisowa języka chorwackiego

- kultura i cywilizacja słowiańskiego obszaru językowego

- kultura i cywilizacja słowiańskiego obszaru językowego i Europy Środkowej

- ortoepia

- wykłady monograficzne

\section{konwersatoria}

- gramatyka opisowa języka słoweńskiego

- gramatyka opisowa języka staro-cerkiewno-słowiańskiego

- ortoepia

- gramatyka opisowa języka chorwackiego

\section{ćwiczenia}

- fonetyka języka polskiego

- seminaria magisterskie na filologii słowiańskiej, słowiańskich językach stosowanych, na pedagogice

- seminaria licencjackie na filologii słowiańskiej, słowiańskich językach stosowanych

- seminarium podyplomowe z balbutologii.

- seminarium podyplomowe z logopedii

- seminarium podyplomowe $\mathrm{z}$ neurologopedii

3. Osiągnięcia przy opracowaniu nowych programów studiów, programów i treści nowych przedmiotów, konstrukcji nowych stanowisk dydaktycznych, programów komputerowych, itp.

opracowanie nowych programu studiów

- filologia słowiańska

- słowiańskie języki stosowane

opracowanie programów i treści nowych przedmiotów

- zob. wyżej obciążenia dydaktyczne

4. Publikacje dydaktyczne (podręczniki, skrypty, artykuły i referaty) podręczniki

1. Slovenščina za Poljake. Kurs podstawowy języka słoweńskiego. Wyd. UŚ. Katowice. 1980 (współautor: Tone Pretnar), ss. 267.

\section{Inne formy udziału w procesie dydaktyczno-wychowawczym}

Hospitacje zajęć dydaktycznych wszystkich pracowników prowadzących zajęcia dydaktyczne na kierunku filologia, specjalności: filologia słowiańska i słowiańskie języki stosowane. 


\section{Formy podnoszenia kwalifikacji zawodowych (kursy itp.)}

Uczestnictwo w kongresach, sympozjach i konferencjach naukowych krajowych i zagranicznych, szkołach letnich.

\section{Wykłady gościnne}

- wykłady gościnne w ośrodkach akademickich zagranicznych (Lublana, Maribor, Koper - Słowenia, Zagreb, Zadar, Dubrovnik - Chorwacja, Wiedeń, Graz, Eisenstadt - Austria)

8. Kształcenie kadr naukowych - efekty (opieka naukowa, promotorstwo w pracach magisterskich i doktorskich)

- merytoryczna opieka naukowa nad studentami i pracownikami naukowo-dydaktycznymi.

\section{- promotorstwo doktoratów}

1. Vladimir Nartnik: Alternativno iskanje slovniških modelov $v$ slovenskem knjižnem jeziku. Katowice 1993.

2. Jaroslav Reska: Reprodukce původni promluvy (na španelském, českém, polském, slovenském a ruském materiálu). Katowice 1998.

3. Robert Bońkowski: Chorwackie słownictwo sportowe. Wydawnictwo „Śląsk”. Katowice 1999.

4. Monika Korchel: Konstrukcje bezosobowe w języku polskim i chorwackim. Katowice 1999.

5. Agnieszka Pianka: Socjolingwistyczne aspekty współczesnego języka bośniackiego. Wyd. Radamsa. Kraków 2000.

6. Tomasz Czapik: Od utopii iliryjskiej do narodzin rzeczywistości jugosławiańskiej. Katowice 2000.

7. Michał Lisecki: Pragmatyczne i socjolingwistyczne aspekty komunikacji przez komputer (KPK). Katowice 2003.

8. Antonina Szybowska: Język gestów i postaw w Kościele rzymsko-katolickim po II Soborze Watykańskim. Katowice 2003.

9. Galina Kutriowa Czubala: Lingvističeskije aspiekty bielorusskich piesienno-magičeskich formul (Aspekty lingwistyczne białoruskich pieśniowych formut magicznych). Katowice 2003.

10. Lilianna Miodońska: Współczesny standard serbski. Katowice 2004. (L. Miodońska: Wspótczesny standard języka serbskiego. Wyd. Naukowe ATH. Bielsko-Biała 2006).

11. Artur Ślęzak: Socjolingwistyczne aspekty języka burgenlandzkich Chorwatów. Katowice 2004. (A. Šlęzak: Burgenlandzcy Chorwaci i ich tradycje językowe. Wyd. Naukowe ATH. Bielsko-Biała 2006).

12. Marcin Baniowski: Pojęcie Europy w języku słoweńskim. Katowice 2004. (M. Baniowski: Pojęcie Europy w języku stoweńskim. Wyd. Naukowe ATH. Bielsko-Biała 2006).

13. Dorota Chłopek: Kategoryzacja słownictwa poprzez „leksykozbiory”zasobów internetowych. Katowice 2005. (D. Chłopek: Kategoryzacja stownictwa poprzez „leksykozbiory"zasobów internetowych. Wyd. ATH. Bielsko-Biała 2007).

14. P. Brom: Czarnogórski standard wobec różnicowania językowego dawnej Jugosławii. Katowice 2007. (P. Brom: Czarnogórski standard wobec różnicowania językowego południowej Stowiańszczyzny. Wyd. ATH. Bielsko-Biała 2007). 
15. Krzysztof Feruga: Język Chorwatów okolic Molise (socjolingwistyczne uwarunkowania). Katowice 2008. (K. Feruga: Język diaspory Molizańskich Chorwatów. Wyd. ATH. Bielsko-Biała 2009).

16. M. Warchał: Językowe (re)konstrukcje tożsamości (psycho- i etnolingwistyczna analiza chorwackich wypowiedzi narracyjnych. Katowice 2010.

\section{- promotorstwo magisteriów}

- 250 magistrów na filologii słowiańskiej i pedagogice w UŚ.

- 150 magistrów na filologii słowiańskiej w ATH.

\section{- promotorstwo licencjatów}

- 150 licencjatów na filologii słowiańskiej w UŚ.

- 100 licencjatów na filologii słowiańskiej w ATH.

\section{- promotorstwo prac podyplomowych}

- 60 dyplomantów na logopedii w UŚ.

- 60 dyplomantów na logopedii w ATH.

- 40 dyplomantów na neurologopedii w ATH.

\section{- recenzje rozpraw doktorskich}

1. Recenzja rozprawy doktorskiej mgr Agnieszki Będkowskiej-Kopczyk pt. Nienawiść $w$ języku polskim i stoweńskim - konceptualizacja i komunikacja. UŚ, 16.02.2000, promotor. prof. zw. dr hab. I. Nowakowska-Kempna.

2. Recenzja rozprawy doktorskiej mgr Barbary Popiołek pt. Terminologia anatomiczna chorwacka i serbska. Ksztaltowanie się jej i funkcjonowanie we wspótczesnych językach. UJ, 25.09.2001, promotor. prof. dr hab. W. Boryś.

3. Recenzja rozprawy doktorskiej mgr Katarzyny A. Ciągwy Socjolingwistyczne wykładniki języka Stowaków na pograniczu polsko-słowackim (na przykładzie pótnocnego Spisza). UŚ, 19.12.2003, promotor. prof. zw. dr hab. I. Nowakowska-Kempna.

4. Małgorzata Urban: Stowotwórstwo przymiotników odrzeczownikowych z wybranymi formantami sufiksalnymi, prom. prof. dr hab. K. Kallas, obrona: Rada Wydziału Filologicznego UMK, 18.05.2004.

5. Elżbieta Kaczmarska: Nominalizacje odczasownikowe w języku czeskim i polskim, prom. prof. dr hab. D. Rytel-Kuc, obrona: Rada Wydziału Polonistyki UW, 25.05.2004.

6. Kaproń-Charzyńska: Rzeczownikowe i przymiotnikowe derywaty ujemne we wspótczesnym języku polskim, prom. prof. dr hab. K. Kallas, obrona: Rada Wydziału Filologicznego UMK, 05.10.2004.

7. Polonca Šek-Mertük: Raba trpnika v slovenskem knjižnem jeziku 19. stoletja. Filozofska fakulteta Univerze v Mariboru, Maribor, maj 2008.

8. Natalija Ulčnik: Besedje Agustičevega časopisa Prijatelj-prikaz v zgodovinskem slovarju prekmurskega jezika. Filozofska fakulteta Univerze v Mariboru, Maribor, grudzień 2008.

9. Maja Jasińska, Wypowiedzi performatywne w jezyku słoweńskim. Wydział Filologiczny Uniwersytetu Śląskiego, Sosnowiec 27.06.2012.

10. Paweł Kowalski, Porabscy Słoweńcy i ich język. Wydział Filologiczny Uniwersytetu Łódzkiego, 12. Łódź 12.10.2012.

11. Justyna Misty-Ślęzak, Wpływ języka angielskiego na współczesną słoweńszczyznę. Analiza anglicyzmów na podstawie młodzieżowego czasopisma Smrklja. / Vpliv angleščine na sodobni slovenski jezik. Analiza anglicizmov na podlagi najstniške revije Smrklja. Wydział Filologiczny Uniwersytetu Śląskiego, Sosnowiec 13.05.2013. 
12. Magdalena Baer, Ewolucja języka chorwackiego przekładów tacińskich hymnów koscielnych - od spiewnika Citchara Octochorda (1701) do zbioru ojca Milana Pavelicia (1945). Wydział Filologii Polskiej i Klasycznej Uniwersytetu A. Mickiewicza, Poznań 22.05.2013.

13. Michał Domański, Manipulacja strachem poprzez język - Aspekt komunikacyjny terroryzmu. Na podstawieopisów wydarzeń w Budionnowsku, Moskwie i Biesłanie. Wydział Filologiczny Uniwersytetu Śląskiego, Sosnowiec 04.06.2013.

\section{- recenzje rozpraw habilitacyjnych}

1. Recenzja habilitacyjna dr Anny Zych (Rada Wydziału Filologicznego UŚ, 18.01.2000) Struktura i semantyka polskich i rosyjskich gniazd stowotwórczych z przymiotnikami wyjściowymi nazywającymi barwę. Wyd. UŚ. Katowice 1999, ss. 231.

2. Recenzja habilitacyjna dr M. Cichońskiej (Rada Wydziału Filologicznego UŚ, 21.05.2002) Wyrażenia zaimkowe w ksztaltowaniu dyskursu potocznego. (Na materiale sztokawskiego systemu językowego ze szczególnym uwzględnieniem języka mieszkańców Sarajewa). Wyd. UŚ. Katowice 2000, ss. 121.

3. Recenzja habilitacyjna dr A. Spagińskiej-Pruszak. (Uniwersytet Gdański, Rada Wydziału Filologiczno-Historycznego - 22.09.2003) Intelekt we frazeologii polskiej, rosyjskiej i chorwackiej. Wyd. UG. Gdańsk 2003, ss. 303.

4. Recenzja habilitacyjna dr Joanny Sławińskiej. Uniwersytet w Lublanie. Wydział Filozoficzny. Katedra Slawistyki 06.11.04.

5. Recenzja habilitacyjna dr W. Kryzia: Polskie i stoweńskie predykaty modalne o znaczeniu ,chcieć', ,musieć', ,powinien 'na poszerzonym tle słowiańskim. Wyd. UŚ. Katowice 2005, ss. 128. kolokwium habilitacyjne Rada Wydziału Filologicznego UŚ 15.11.2005.

6. dr Barbara Oczkowa: Chorwaci i ich język. Z dziejów kodyfikacji normy literackiej, Kraków 2006, s. 360. (rec. CK d/s SniTN - 20.04.2007, przewód hab. 6.12.2007).

7. dr Ewa Straś: Kategoria intensywności we frazeologii języka polskiego i rosyjskiego. Wyd. UŚ. Katowice 2008. - Wydział Filologiczny Uniwersytetu Śląskiego.

8. dr. Nataliji Ulčnik w zwiazku z mianowaniem na etat docenta w Katedrze Slawistyki Wydziału Filozoficznego Uniwersytetu w Mariborze. Maribor 2009.

9. dr Robert Bońkowski, Stowianie środkowopołudniowi na przełomie XX i XXI wieku. Język - Religia - Naród - Państwo, Agencja Artystyczna PARA, Uniwersytet Śląski, Katowice 2010, ss. 351, kol. hab. Wydział Filologiczny UŚ, Katowice 13.12.2011.

10. dr Maciej Czerwiński, Semiotyka dyskursu historycznego. Chorwackie i serbskie syntezy dziejów narodu. WUJ, Kraków 2012. Wydział Filologiczny UJ, Kraków 24.09.2013.

\section{- recenzje dorobku naukowego na stanowisko profesora}

1. Recenzja na stanowisko profesora nadzwyczajnego Uniwersytetu Śląskiego dr hab. Marii Teresy Michalewskiej prof. UŚ (Wydział Pedagogiki i Psychologii), 1999 r.

2. Recenzja na stanowisko profesora nadzwyczajnego Uniwersytetu Śląskiego dr hab. Krystyny Jarząbek (Wydział Filologiczny UŚ), marzec 2000 r.

3. Recenzja na stanowisko profesora nadzwyczajnego Uniwersytetu Śląskiego dr. hab. Ludwiga Selimskiego (Wydział Filologiczny UŚ), 15.08.2002.

4. Mnenje o znanstvenem, pedagoškem in organizacijskem delu gosp. dr. Marka Jesenška, izrednega profesorja za slovenski jezik v zvezi s postopkom za izvolitev v naziv redni profesor za slovenski jezik (22.07.2005).

5. Recenzja na stanowisko profesora nadzwyczajnego Uniwersytetu Gdańskiego dr hab. Agnieszki Spagińskiej-Pruszak (Wydział Humanistyczny UG), styczeń 2008 r. 
6. Recenzja na stanowisko profesora nadzwyczajnego Uniwersytetu Jagiellońskiego dr hab. Barbary Oczkowej (Wydział Filologiczny Uj), styczeń 2008 r.

\section{- recenzje dorobku naukowego na tytuł profesora}

1. Recenzja do tytułu profesora nauk humanistycznych dra hab. Henryka Fontańskiego, prof. UŚ - 1999.

2. Recenzja do tytułu profesora nauk humanistycznych dra hab. Jadwigi Koniecznej-Twardzikowej, prof. UŚ - 2001.

3. Recenzja do tytułu profesora nauk humanistycznych dr. hab. Marka Jesenška, Uniwersytet w Mariborze - 2005.

4. Recenzja do tytułu profesora nauk humanistycznych dr hab. Bożeny Ostromęckiej-Frączak, Uniwersytet Łódzki - 2007.

5. Recenzja naukowa prof. dr. Mihaeli Koletnik w zwiazku z mianowaniem na etat profesora zwyczajnego w Katedrze Slawistyki Wydziału Filozoficznego Uniwersytetu w Mariborze. Maribor 2009.

6. Recenzja do tytułu profesora nauk humanistycznych dra hab. Michała Labaschuka, prof. ATH - 2013.

\section{DZIAŁALNOŚĆ W ZAKRESIE ORGANIZACJI, DYDAKTYKI, BADAŃ NAUKOWYCH I ŻYCIA UCZELNI}

\section{Działalność w zakresie organizacji nauki}

- Organizator Zakładu Filologii Słowiańskiej Instytutu Filologii Obcych na Wydziale Filologicznym Uniwersytetu Śląskiego w Katowicach - 01.10.1973.

- Organizator Katedry Filologii Słowiańskiej Wydziału Filologicznego Uniwersytetu Śląskiego w Katowicach 1.10.1985.

- Organizator Instytutu Filologii Słowiańskiej Wydziału Filologicznego Uniwersytetu Śląskiego w Katowicach 1.10.1989.

- Współorganizator Podyplomowego Studium Logopedii i Glottodydaktyki przy Wydziale Filologicznym Uniwersytetu Śląskiego w Katowicach 01.10.1994.

- Współorganizator Wydziału Humanistyczno-Społecznego ATH - 01.06.2002.

- Organizator Katedry Studiów Środkowoeuropejskich ATH - 01.10.2002.

\section{Sprawowanie funkcji czlonka organów kolegialnych}

- członek Senatu UŚ

- członek Senatu ATH

- członek Rady Wydziału Filologicznego UŚ

- członek Rady Naukowej Instytutu Filologii Słowiańskiej UŚ

- członek Rady Wydziału Humanistyczno-Społecznego ATH

- przewodniczacy Rady Wydziału Humanistyczno-Społecznego ATH

3. Sprawowanie funkcji kierowniczych w jednostce organizacyjnej, komisjach, radach

- kierownik Katedry Filologii Słowiańskiej UŚ

- kierownik Zakładu Językoznawstwa Południowosłowiańskiego UŚ

- dyrektor Instytutu Filologii Słowiańskiej UŚ

- kierownik Katedry Studiów Środkowoeuropejskich ATH

- prorektor ds. Nauki i Współpracy Zagranicznej ATH

- dziekan Wydziału Humanistyczno-Społecznego ATH 
- kierownik Katedry Anglistyki ATH

- kierownik Podyplomowego Studium Naeurologopedii ATH

4. Uczestniczenie w pracach komisji, rad i innych zespołów w ramach uczelni, wydziału, katedry

Uczestniczenie w pracach:

- Senatu UŚ

- Rady Wydziału Filologicznego UŚ

- Senat ATH

- Rada Wydziału Humanistyczno-Społecznego ATH

5. Sprawowanie funkcji opiekuna (grupy studenckiej, roku, specjalności, studiów doktoranckich, praktyk studenckich itp.)

- opiekun naukowy studiów magisterskich, licencjackich, podyplomowych

- opiekun naukowy pracowników katedry o specjalności językoznawstwo

\section{Uzyskane odznaczenia}

nie posiada

\section{Uzyskane nagrody i wyróżnienia za osiągnięcia w działalności na rzecz uczelni}

- nagroda indywidualna JM Rektora UŚ, JM Rektora ATH

- nagroda państwowa Republiki Słowenii: Ambasador słoweńskiej kultury im. T. Pretnara (2007)

- nagroda państwowa Republiki Słowenii: Ambasador słowiańskich kultur (2012). Univerza v Ljubljani. Uhonorowanie prof. E. Tokarza złotym medalem Universitas Labacensis za promocję nauki polskiej za granicą, Ljubljana 03.12.2013.

\section{Osiągnięcia z działalności poza uczelnią}

- stały kontakt i współpraca z ambasadami i konsulatami państw środkowoeuropejskich

- organizacja stałej współpracy z uniwersytetami południowosłowiańskimi (szczególnie chorwackimi i słoweńskimi)

- członek Rady Redakcyjnej Slavii Centralis (Maribor, Słowenia)

- nagrody państwowe Republiki Słowenii

\section{Działalność w organizacjach i towarzystwach naukowych}

- członek Polskiego Towarzystwa Językoznawczego

- członek Slavističnega društva Sloveniji w Słowenii

- pierwszy przewodniczący i członek Towarzystwa Polsko-Słoweńskiego

- członek Komisji Językoznawczej PAN Oddział Katowice

- członek Towarzystwa Miłośników Języka Polskiego

- członek Towarzystwa Naukowego w Toruniu 